\title{
Changes of Georgian Mountainous Rivers Water Flows, Problems and Recommendations
}

\author{
Tsisana Basilashvili \\ Institute of Hydrometeorology, Georgian Technical University, Tbilisi, Georgia \\ Email address: \\ jarjinio@mail.ru \\ To cite this article: \\ Tsisana Basilashvili. Changes of Georgian Mountainous Rivers Water Flows, Problems and Recommendations. American Journal of \\ Environmental Protection. Special Issue: Applied Ecology: Problems, Innovations. Vol. 4, No. 3-1, 2015, pp. 38-43. \\ doi: 10.11648/j.ajep.s.2015040301.17
}

\begin{abstract}
As a result of Global warming the Caucasus glaciers increasingly start melting, which in its turn leads to the higher water flows and disasters. While in drier regions evaporation increases, the water levels in the rivers decrease and the crops dwindle. In the long run, some of the glaciers will disappear, which will have a negative impact on water resources, water supply will lower and the country's economic development will be halted. For increasing water resources, reforestation is a solution as forests play a vital and regulating role for superficial and underground water supplies. Forests enhance the quality of water and increase its supply and discharge. Forests strengthen the soil and prevent erosion, landslides, high water flows, floods and avalanches. Thus, the more forests the less negative consequences. In agricultural lands, forests are needed to protect vegetation and soil from emaciating and drying. In the dry climate regions water reservoirs must be built in the terrains which permit to do so, which will resist to serious water flows, mitigate the consequences of disaster and supply water to farms and population during the dry spells. For protecting river waters from the elements, for their rational utilization and effective and safe exploitation having forecasts of water flows is vital. In East Georgia work to increase rainfall artificially should be restored, which in its turn will protect the region from hail. For obtaining technical water technologies for turning salty sea water into fresh one should be utilized.
\end{abstract}

Keywords: multi-year dynamics, water resources, forest

\section{Introduction}

The world is constantly changing. Over the 4,5 billion years, the earth has undergone multiple changes. Humankind met the XXI century with a seriously complicated ecological condition. Now, we are extremely worried about the climate change caused by global warming. Besides its positive feedback, modern technologies also created the self-destruction possibility for live nature [1].

Temperature growth on earth was caused not only by the man-made factor (carbon dioxide emission into the atmosphere), but by activation of the ongoing processes on the sun's surface and depletion of the ozone layer as well (the earth shield absorbing UV radiation from the sun). Climate change caused by such "greenhouse effect" is a really pressing problem for the world and the most important and potential danger to our environment. Ongoing climate fluctuations contribute to strengthening of climate contrast range, imbalance of humidity distribution on earth and the existing created situation in this regard [2].

Fresh water resources are one of the most complex issues nowadays that deserve appropriate attention from our side. Life on earth totally depends on these resources as well as each country's economy and development. Nature protection, rational use and reproduction of its resources is the basis for sustainable development of any country's economy. The climate-related crisis and anomalies caused by global warming and happening on earth (in real space and time) exert huge influence on natural resources, particularly on water and land resources. Against this background, the risk of development of any country is daily increasing, mainly caused by reduction of the volume of water resources, their quality deterioration and frequent natural disasters [3-4].

\section{Study Area}

Diverse landscape, relief and climate are characteristic to Georgia, starting from the moist subtropical zone of the Black Sea, eastern part and ending with the highland alpine Nival 
climate on Great Caucasus. Mountains occupy nearly $85 \%$ of Georgia's territory (fig. 1). Among other risks, floods/flash flows and water erosion processes are on top of the list in Georgia, as well as the sea coastline wash off, landslides, mudflows and snow/glacier avalanches. In this regard, considering the scale of the development of similar processes and their negative consequences, Georgia is an outstanding region among other highland countries. Floods and flash flows are typical for all rivers in the mountains and lowlands here as they are conditioned by the density of hydrographic network, the specificity of the relief and climatic-meteorological regime. Density of rivers' network is average $0,85 \mathrm{~km} / \mathrm{km}^{2}$. Regarding the distribution of atmospheric precipitations, this coefficient is $1,07 \mathrm{~km} / \mathrm{km}^{2}$ in West due to moist, while it is $0,68 \mathrm{~km} / \mathrm{km}^{2}$ in dry East [5].

Danger of floods is especially big in foothills and lowland relief. As a result of massive precipitations, rivers overflow and flood territories, settlements, cities, roads, hundreds of arable get lost and often we face victims as well. Similar processes were described in the ancient historical sources in Georgia [6-7]. The fact should be noted that earlier, the population used to reside mainly in the mountains, while the flooded rivers caused no danger to lowlands. Even more, flooding fertilized and enriched soils that later resulted in crop productivity. Though, in parallel to the population's propagation, people started organizing their living habitats near rivers, thus increasing the risk of danger. The $2 / 3$ of the recorded floods/flash flows falls at West Georgia rivers due to the fact that West Georgia is characterized with prolonged and heavy rains. Besides that, present eustasy - uniform worldwide change in sea level caused by water thermal expansion, imbalance of fresh waters between the land and the ocean in favour of the ocean, seriously threatens Black sea coastline, where the sea level has raised by $20 \mathrm{~cm}$ and this is a continuous process with unfavorable forecast. This vivid example is figure 2 , that shows the flooding result happened on 198731 January in river Rioni lower element near the Black Sea caused by heavy showers and intense melting of snow avalanche [7].

In order to study the impact of the ongoing climate change caused by global warming, research on the change of dynamics of quantities of Hydrometeorological processes shall take a leading position. With this purpose, we discussed analysis of the rows of multi-year observations made in the Hydrometeorological network on the territory of Georgia. In this regard, rather important is the qualitative and the quantitative definition of multi-year dynamics of these elements. This implies assessment of trends in an equation reflecting their rectilinear approximation:

$$
\mathrm{T}=\mathrm{a} \mathrm{N}+\mathrm{b}
$$

where $\mathrm{T}$ - is a trend - averaged straight line reflecting the tendency of multi-year change of the element at research; $\mathrm{N}$ is an ordinal number of observation data of this element starting from their initial year, for which $\mathrm{N}=1$, for each following ( $\mathrm{i}$ ) year $\mathrm{N}=1+\mathrm{i}$; a - is a coefficient of the equation, its mark (+ or -) indicates at direction of change of the element at research: positive $(+)$ mark expresses its growth, i.e. ascending tendency, while negative (-) mark shows decline of the element at research, i.e. descending tendency. a itself - quantitative meaning of the parameter defines intensity of the change of the element at research, i.e. speed; $b$ - is an equation constant.

Table 1 gives $a$ and $b$ parameters of the equation received from approximation of the trends reflecting the multi-year change (60-70 years) until 2010 on meteorological stations operating in West and East Georgia, atmospheric precipitations and air temperature. As the table data show, due to global warming, climate in separate regions of Georgia is getting colder rather than warmer. For example, in some regions of West Georgia, the weather gets colder, while in East Georgia, it gets warmer and air temperature growth is expected.

Table 1. Parameters (a, b) of atmospheric precipitations (R) and air temperature trends $(\theta)$.

\begin{tabular}{lllllll}
\hline River & $\begin{array}{l}\text { Meteo } \\
\text { Station }\end{array}$ & Height & $\mathbf{a}_{\mathbf{R}}$ & $\mathbf{b}_{\mathbf{R}}$ & $\mathbf{a}_{\boldsymbol{\theta}}$ & $\mathbf{b}_{\boldsymbol{\theta}}$ \\
\hline West Georgia & & & & & \\
\hline Bzifi & Gagr. Ridge & 1644 & 1,925 & 1623 & $-0,005$ & 6,02 \\
Kodori & Lata & 299 & 0,259 & 1859 & $-0,013$ & 12,45 \\
Enguri & Mestia & 1441 & $-1,378$ & 998 & $-0,004$ & 5,90 \\
Enguri & Khaishi & 730 & - & - & $-0,011$ & 10,89 \\
Rioni & Mamisoni & 2854 & - & - & 0,008 & $-2,27$ \\
Rioni & Lentekhi & 760 & 2,637 & 1211 & 0,004 & 9,39 \\
Rioni & Ambrolauri & 544 & 1,473 & 1008 & $-0,010$ & 11,50 \\
Rioni & Kutaisi & 114 & $-1,421$ & 1499 & $-0,013$ & 0,01 \\
Kvirila & Saqara & 148 & 0,179 & 1255 & 0,004 & 14,02 \\
Supsa & Bakhmaro & 1926 & $-3,974$ & 1630 & 0,006 & 4,00 \\
Acharisck. & Khulo & 923 & & & 0,002 & 10,40 \\
Acharisck. & Qeda & 256 & 5,517 & 1541 & $-0,010$ & 12,96 \\
East Georgia & Kazbegi & 3653 & $-4,613$ & 1865 & - & - \\
Aragvi & Gudauri & 2194 & $-1,934$ & 1579 & 0,012 & 2,13 \\
Aragvi & Barisakho & 1325 & $-2,466$ & 1150 & 0,001 & 6,96 \\
Aragvi & Pasanauri & 1070 & $-1,358$ & 928 & 0,007 & 7,95 \\
Aragvi & Telavi & 568 & $-1,183$ & 831 & 0,005 & 12,08 \\
Alazani & Lagodekhi & 362 & $-2,318$ & 1086 & 0,767 & 30,10 \\
Alazani & Lang & & & & & \\
\hline
\end{tabular}

All the discussed meteo-points in East Georgia show significant reduction of atmospheric precipitations, while their reduction is observed in separate places of West Georgia (Mestia, Kutaisi, Bakhmaro); the rest stations in dicate at increase of precipitations.

In order to study the change in river runoff, we discussed the 50-70 year observation rows of average annual discharge on rivers of Georgia $\left(\mathrm{Q}, \mathrm{m}^{3} / \mathrm{sec}\right)$, also their annual maximal discharge $\left(\mathrm{Q}_{\mathrm{m}}, \mathrm{m}^{3} / \mathrm{sec}\right)$, as they represent the main source of natural disaster developments. Table 2 provides the research results. Based on the analysis, in multi-year dynamics of average annual discharge, decrease tendency is observed in these river basins, where there are no glaciers and eternal snow coverage. There are exceptions in this regard; e.g. river Adjaristskhali, with no Nival zone, water average annual discharge is increased. The reason is that according to Table 1, the highest intensity of growth of atmospheric precipitations $(\mathrm{R}, \mathrm{mm})$ is observed in this river basin $(\mathrm{m} / \mathrm{s}$ Keda), which is depicted as follows: 


$$
\mathrm{T}_{\mathrm{R}}=5,517 \mathrm{~N}+1541,
$$

Descending (decreasing) trend of air temperature $\left(\theta^{\circ} \mathrm{C}\right)$ is reflected as the following equation:

$$
\mathrm{T}_{\theta}=-0,01 \mathrm{~N}+12,96 \text {. }
$$

Closeness to the Black Sea caused this fact in the river Ajaristskhali basin, where cold, moist air masses are intensively (compared to an earlier period) intruding.

Dynamics of rivers' maximal discharge sharply outlines the growth tendency, if the glaciers and melted permanent snow waters participate in their enrichment. Growth of maximal discharge in the river Kvirila basin is an exception in this regard, notwithstanding the absence of glaciers here. Pursuant to the data from Table 1, atmospheric precipitations significantly increase in this river basin $(\mathrm{m} / \mathrm{s}$ Saqara) due to intrusion of Black Sea moist air masses.

From the river basins discussed in the table 2, river Rioni is distinguished by the highest intensity of water discharge growth and feeds (partially) from the glacier and melted permanent snow waters. Counting of observation years on river Rioni (at village Saqochakidze) begins from 1928, for which $\mathrm{N}=1$. The trend relevant to the dynamics of average annual discharge is given as following equation:

$$
\mathrm{T}_{\mathrm{Q}}=1,303 \mathrm{~N}+372 \text {, }
$$

The biggest intensity of the annual discharge drop is observed on river Chorokhi, the trend of the change in the nearby territory of its mouth (near village Erge) can be read as the following equation:

$$
\mathrm{TQ}=-0,458 \mathrm{~N}+290 .
$$

Ajaristskhali is characterized by the biggest intensity of river water maximal discharge drop $\left(\mathrm{a}_{\mathrm{Qm}}=-2,95\right)$, while the biggest intensity of growth $\left(\mathrm{a}_{\mathrm{Qm}}=35,5\right)$ is observed at village Saqochakidze, river Rioni. Multi-year dynamics of maximal discharge of these rivers with relevant trends is given in the fig. 3.

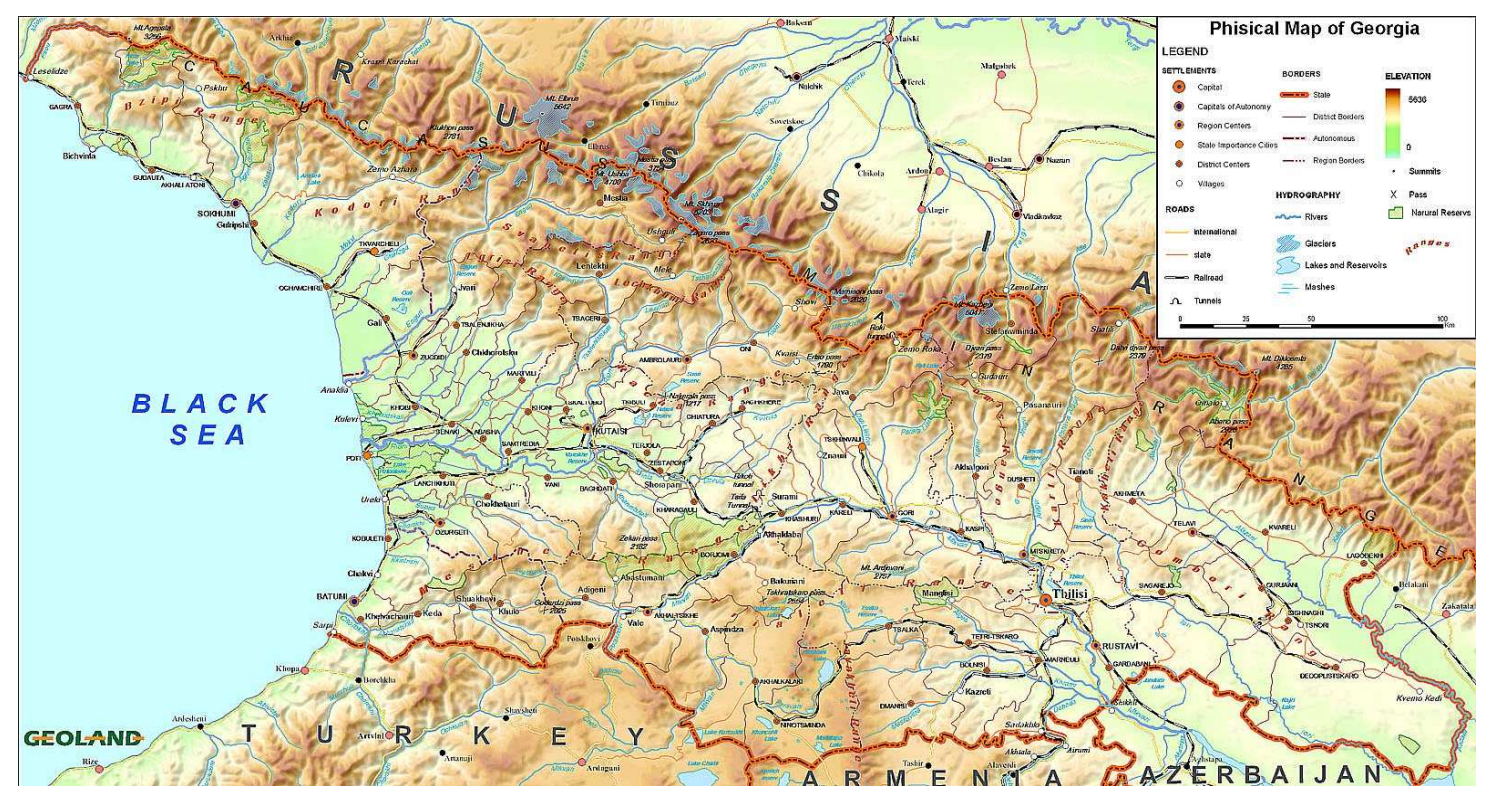

Figure 1. Map of Georgia.

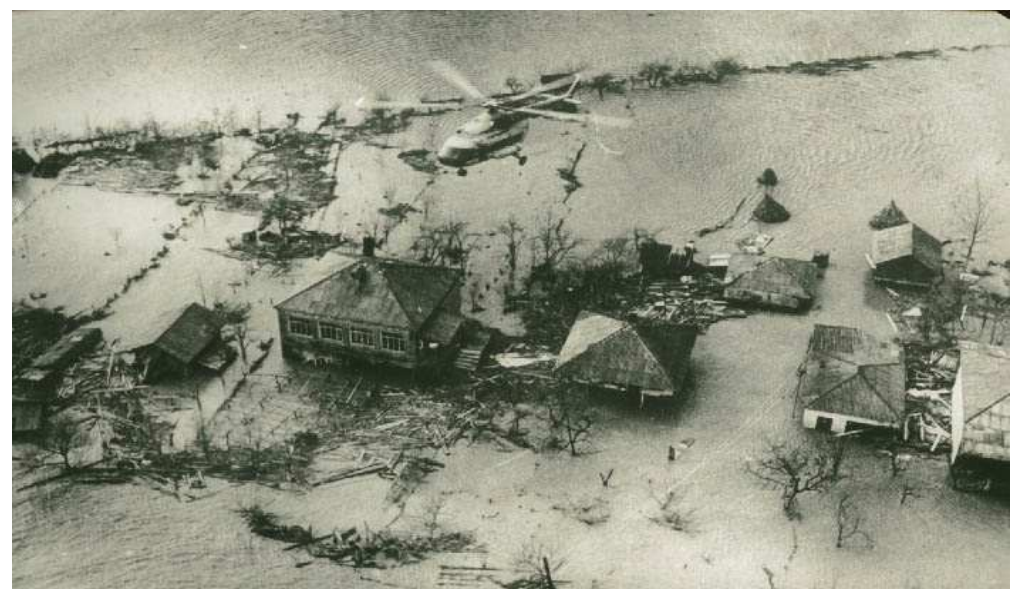

Figure 2. Catastrophic flooding on River Rioni on 31 of January, 1987 at vil. Chaladidi. 
Table 2. Trend parameters of average $(Q)$ and maximal $(Q m)$ water discharge of Georgia 's rivers.

\begin{tabular}{|c|c|c|c|c|c|c|c|}
\hline \multirow{2}{*}{ River } & \multirow{2}{*}{ Place } & \multirow{2}{*}{$\begin{array}{l}\text { Area } \\
\mathbf{k m}^{2}\end{array}$} & \multirow{2}{*}{$\begin{array}{l}\text { Height } \\
\text { m. }\end{array}$} & \multicolumn{2}{|c|}{ Average } & \multicolumn{2}{|c|}{ Maximal } \\
\hline & & & & $\mathbf{a}_{\mathbf{Q}}$ & $\mathbf{b}_{\mathbf{Q}}$ & $\mathbf{a}_{\mathbf{Q m}}$ & $\mathbf{b}_{\mathrm{Qm}}$ \\
\hline Kodori & Lata & 1480 & 1920 & 0,357 & 81,2 & 5,92 & 310 \\
\hline Enguri & Khaishi & 2780 & 2320 & 0,960 & 89,4 & 8,50 & 319 \\
\hline Rioni & Saqochakidze & 13300 & 2620 & 1,303 & 372 & 35,5 & 828 \\
\hline Kvirila & Zestafoni & 2490 & 960 & $-0,028$ & 61,6 & 0,83 & 504 \\
\hline Chorokhi & Erge & 22000 & - & $-0,458$ & 290 & $-0,80$ & 1369 \\
\hline Acharisck. & Qeda & 1360 & 1470 & 0,118 & 43,0 & $-2,95$ & 391 \\
\hline D. Liakhvi & Kekhvi & 924 & 2100 & 0,114 & 24,4 & 0,85 & 115 \\
\hline P. Liakhvi & Vanati & 422 & 1940 & $-0,014$ & 10,3 & $-0,43$ & 62,1 \\
\hline Ksani & Korinta & 461 & 1830 & $-0,070$ & 11,2 & $-0,50$ & 72,2 \\
\hline Alazani & Birkiani & 282 & 2200 & $-0,002$ & 14,0 & $-1,08$ & 98,4 \\
\hline Alazani & Shaqriani & 2190 & 1210 & 0,050 & 43,8 & $-1,18$ & 348 \\
\hline Aragvi & Jinvali & 1900 & 1890 & 0,028 & 44,1 & - & - \\
\hline T. Aragvi & Mleta & 107 & 2620 & 0,008 & 5,08 & - & - \\
\hline Sh. Aragvi & Shesartavi & 240 & 2020 & $-0,008$ & 7,84 & - & - \\
\hline F. Aragvi & Magaroskari & 945 & 1960 & 0,052 & 17,6 & - & -- \\
\hline Khadiskhevi & Tskere & 18,8 & 2500 & 0,005 & 0,87 & - & - \\
\hline Iori & Lelovani & 494 & 1640 & 0,934 & 12,7 & - & - \\
\hline
\end{tabular}

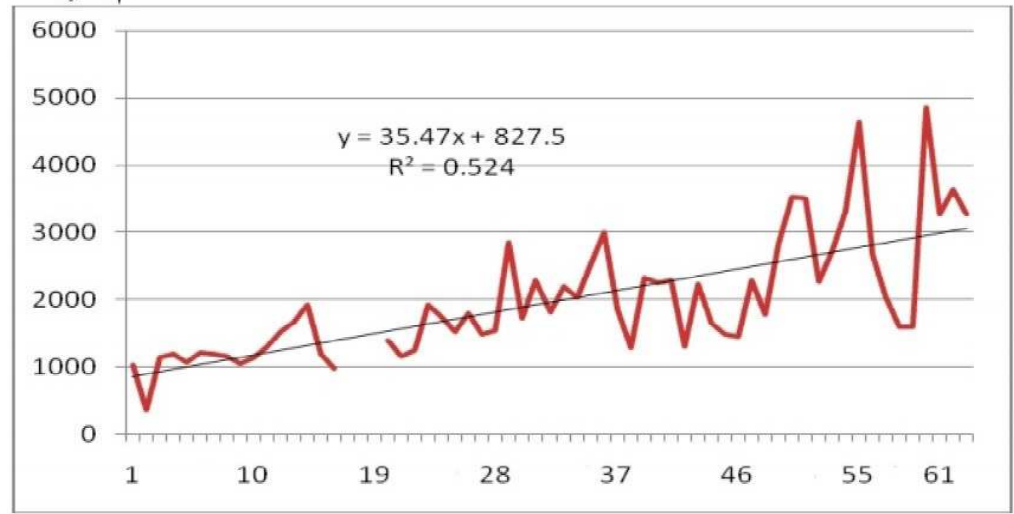

$\mathrm{Q}_{\mathrm{m}}, \mathrm{m}^{3} / \mathrm{s} \mathrm{A}$

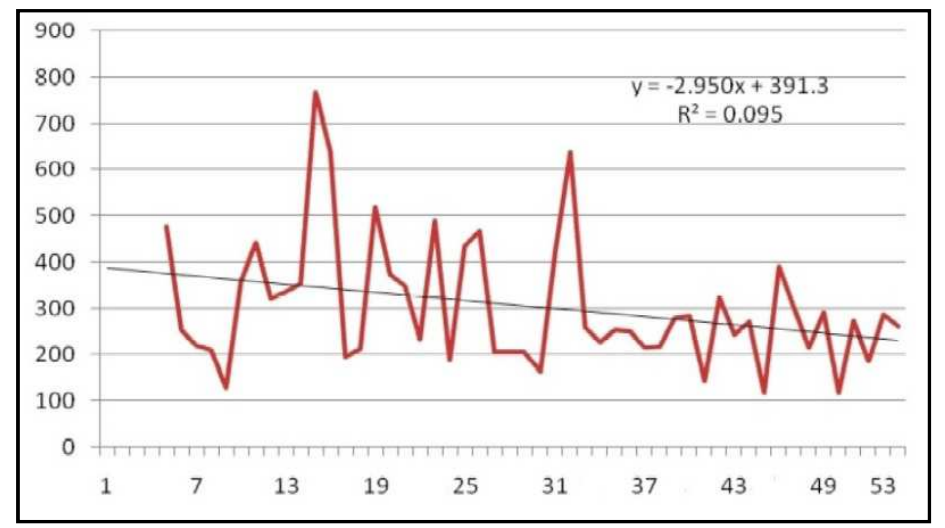

$\mathrm{Q}_{\mathrm{m}}, \mathrm{m}^{3} / \mathrm{s} \mathrm{B}$

Figure 3. Dynamics of maximal water discharge $\left(Q_{m}, \mathrm{~m}^{3} / \mathrm{s}\right)$ on river Rioni $(A)$ and Ajaristskhali $(B)$.

\section{Results and Discussion}

In the XXI century, evaporation will also rise in parallel to air temperature growth due to global warming [8]. Accordingly, liquid precipitations will increase and snow coverage area decrease, glacier melting will become intensive, underground water levels will lower as well as the runoff in river water scarcity period, while runoff in water abundancy period will go up and floods start to occur frequently. Expected climate change will result in droughts, floods, water deficit during on one hand and increased flooding-inflicted damage, on the other. 
Humankind has been struggling against natural disasters for many years already, though has not found reliable tools yet and the floods happening everywhere around (including Georgia) with its accompanying tragic results confirm that. Science and technology are unable to deal with the causing factors of ongoing global climate processes and is forced to be limited only with searching for different tools to eliminate the consequences. In order to reduce the negative impact of floods and flash flows, we developed specific recommendations based on the analysis.

Each year, as soon as flooding ends, to ensure smooth ending of the next year flooding period, riverbed conductivity and admissible depths of river ravines shall be maintained. For that shall be conducted: cleansing of riverbeds, protecting the banks with dams, dikes and bulwarks; shall also be constructed roundabout (release) spillway channels. Besides, slopes of river ravines shall be terraced and different agromelioration measures conducted: across ploughing, selection of plant varieties, etc.

Special attention shall be paid to renewal and expansion of forest on the territories of river basins, as it protects and strengthens the soil on mountain slopes, hinders the process of erosion, mudflows, landslide and snow avalanche formation. So, the more wider and expanded the forest and trees are, the less originate the negative processes around.

Forest is one of the most important factors for underground and surface water regulation. It improves quality of underground waters, increases the points (sources) of their release and their discharge. Most importantly, forest stabilizes river water regime and reduces their maximal peak. Forest is the main source of oxygen and is of crucial importance for air purification and human health improvement. It provides favorable habitat for fauna and avifauna propagation. Useful plant varieties shall be selected and selective cutting shall be organized, while windbreak lines shall be placed in agricultural arable to protect plants/soil from losing moist, also hamper the process of soil drying out and its depletion.

Besides that, the reservoir is one of the most effective tool to regulate river waters. It helps to retain huge water masses during flooding, while in water scarcity, it is the main water resource that could be used for water supply of population and farming, to get electricity, develop fishery and most importantly, for hydromelioration, especially in dry climates [9]. In the conditions of favorable and geologically sustainable relief of rivers' ravines, construction of small size reservoirs would be very useful. They will be the most reliable and effective constructions against floods and flash flows. River ravines or dried lake castles could be used for that.

When constructing the reservoir, based on the accurate hydrological calculations, controller's time-tables shall also be developed in a way that will make possible to empty reservoirs in case of emergency, before the flood occurs, i.e. step by step (before the peak) instead of concurrently that could intensify flash flows below. Timely unloads of reservoir and retainment of huge masses of flood will avert damage and victims. This is the reason why the network of small reservoirs shall be expanded more in future. Their construction truly needs big funds, though sometimes flooding of a small mountainous river can cause more damage than those funds spent on the reservoir construction. In the conditions of its proper exploitation, the reservoir will protect the environment and population from natural disasters in the future many times. It will also improve the economy of the country.

The most acceptable and easy method to protect riverside settlements from water-related disasters, is to determine the borders of floods/flash flows and announce this territory as a dangerous zone, where construction of residential and other premises will be prohibited as well as all economical and domestic activities.

\section{Conclusions}

With the aim to maintain ecological sustainability of the environment, ensure population security, avoid flooding of water objects (hydroelectric stations, water supply and irrigation systems), railway and motor roads, agricultural arable, also protect them from other dangers and reduce the damage, most important is to forecast floods and their maximal discharge [10]. Forecasts are also required for planning the rational use of water resources and effective/safe exploitations of water reservoirs.

Development of only forecasts cannot stop natural disasters, it is true, but can play a big role in the reduction of their negative impact. Long-term forecast (1-3 months) of floods' maximal discharge enables to timely carry out all the preventive measures in case when the expected water is at its peak, protect all the objects at risk and avoid damage/victims. So, forecast of maximal river discharge, even in terms of consultations at the initial stage, shall be rapidly delivered to the relevant organizations to enable them to timely warn the population and if required, conduct evacuation and ensure security of material values. In parallel to this, reservoirs shall be gradually unloaded to receive high water flow.

Population living in highland areas is the initial provider of information re dangerous natural disasters occurring in river ravines. The first signs appear in the form of a terrible buz, or a whirlwind of dust, river water levels can termination of river-flow in case of ravine blockage, etc. Upon the receipt of similar notifications, an alarm shall be rung and all the relevant organizations mobilized in order to provide with all the required preventive measures.

\section{References}

[1] L. Douglas and A.Johnson, "Laurence Levis Land Degradation: Creation and Destruction" 2007, 303 p.

[2] G. Metrevely, N. Tsivtsivadze, M. Goginava, R. Diasamidze and M. Beridze" New approaches of the World Ocean level series analysis" Advanced Problems in Geophysics, Tbilisi, 2014, pp. 226-229.

[3] O.P. Sosnovskaya, "Evaluation of Fresh Water Ecosystems State", Geography: Science and Education Problems, St-Petersburg, 2011, pp. 140-142. 
[4] Wei-Hua Guo, Bo Li, Xin-Shi Zhang and Ren-Qing Wang, "Water Balance in Soil-Plant-Atmosphere-Continum (Spac) and Garagana Intermedia", Environment and Ecology in the Mediterranean Region, Cambridge Scholars Publishing, UK, 2012, pp. 261-270.

[5] "Water Resources of TransCaucasia", edited by G. Svanidze and V. Tsomaia, Hydrometeoizdat, Leningrad, 1988, 264 p.

[6] G. Svanidze and G. Khmaladze, "Freshets and Floods", Hazardous Hydrometeorological Phenomena in Caucasus, Hydrometeoizdat, Leningrad, 1983, pp. 191-210.

[7] Ts. Basilashvili, M. Salukvadze, V. Tsomaia and G. Kherkheulidze, "Catastrophic of Flooding, Mudflow and Avalanches in Georgia and their Safety", Publishing House "Technical University", Tbilisi, 2012, 244 p.
[8] Georgia's Second National Communication to the UNFCCC, Tbilisi, 2009, $230 \mathrm{p}$.

[9] Ts. Basilashvili, J. Tabatadze and M. Janelidze, "River Water Regulation under Modern Climate Change Conditions", Environment and Ecology in the Mediterranean Region, Cambridge Scholars Publishing, UK, 2012, pp. 347-352.

[10] Ts. Basilashvili, "Multifactorial Statistical Methodology for Forecasting Floods-High Water Flows", Publishing House "Technical University", Tbilisi, 2013, 180 p. 